\title{
Managing Public Debt and Its Financial Stability Implications
}

Udaibir S. Das, Michael Papapioannou, Guilherme Pedras, Faisal Ahmed, and Jay Surti 


\title{
IMF Working Paper
}

Monetary and Capital Markets Department

\section{Managing Public Debt and Its Financial Stability Implications \\ Prepared by Udaibir S. Das, Michael Papapioannou, Guilherme Pedras, Faisal Ahmed, and Jay Surti}

Authorized for distribution by Udaibir S. Das

December 2010

\section{This Working Paper should not be reported as representing the views of the IMF.}

The views expressed in this Working Paper are those of the author(s) and do not necessarily represent those of the IMF or IMF policy. Working Papers describe research in progress by the author(s) and are published to elicit comments and to further debate.

\begin{abstract}
This paper explores the relationship between the level and management of public debt and financial stability, and explains the channels through which the two are interlinked. It suggests that the broader implications of a debt management strategy and its implementation should be carefully analyzed by debt managers and policy makers in terms of their impact on the government's balance sheet, macroeconomic developments, and the financial system.
\end{abstract}

JEL Classification Numbers: F34, G15, H63

Keywords: Public Debt Structure, Public Debt Management, Financial Stability

Author’s E-Mail Address: udas@imf.org, mpapaioannou@imf.org, gpedras@imf.org, fahmed@imf.org, jsurti@imf.org

This Working Paper was published as Chapter 15 of the book "Sovereign Debt and the Financial Crisis." The World Bank is the source and copyright holder of this work. This Working Paper is based on an ongoing study by the authors of the recent global economic and financial crisis, cross-country experiences with debt management operations, and their implications for public sector balance sheets and financial stability. 


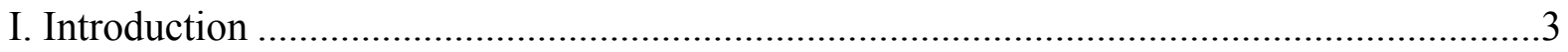

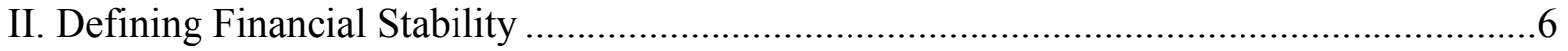

III. Public Debt, Debt Management, and Financial Stability ..............................................

IV. How Debt Management Affects Financial Stability: Some Recent Experiences.............10

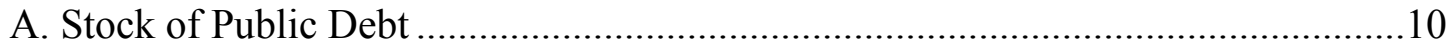

B. Debt Structure and Composition ..................................................................... 11

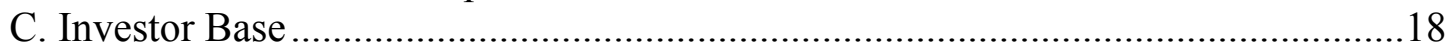

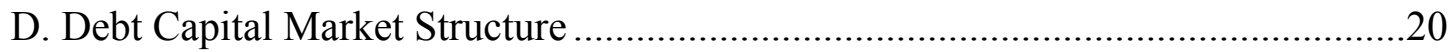

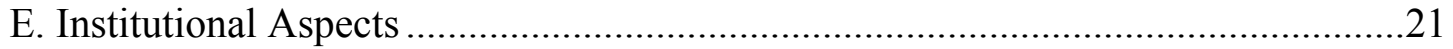

V. Relevance of Debt Management for Various Groups of Countries .................................21

VI. Risk Mitigation Policies .................................................................................22

VII. Concluding Remarks ..........................................................................................25

Table

1. Debt Management Channels to Financial Stability .........................................................24

Figures

1. Gross General Government Debt to GDP Ratio in Selected Emerging Market and Developed Market Economies, 2000 and 2009............................................................9

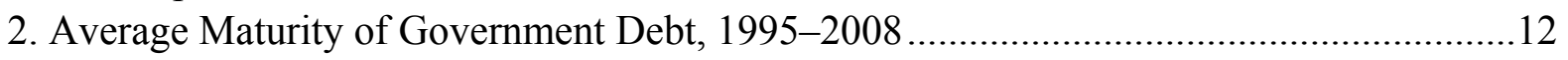

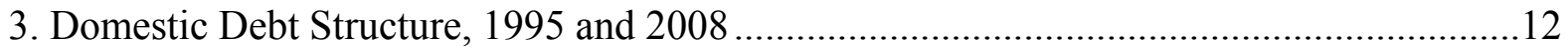

4. Macroeconomic Developments in Brazil, Mexico, and Turkey, 2002-10 .......................15

5. Composition of Public Debt in Turkey, 2002-06 .......................................................... 17

6. Buy and Sell Auctions in Brazil, 2006 and 2008 ........................................................24

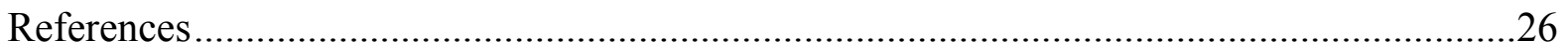




\section{INTRODUCTION}

Sovereign debt has traditionally received much attention as a crucial component of a country's macroeconomic and financial policy framework. Indeed, past crises have been triggered by debt crises. The recently heightened attention on sovereign risk from policy makers and financial markets stems from the realization that how debt is managed considerably influences the soundness and solvency of the overall public sector balance sheet. Debt management is also perceived as an important factor that underpins the credibility and reputation of a sovereign, and conditions the stability of debt capital markets and the financial institutions that hold public debt. The sharp increase in debt levels in developed countries and the recent contagion fears in Euro Area countries through the banking systems have reinforced this perception.

This paper explores the relationship between the level and management of public debt and financial stability, and explains the channels through which the two are interlinked. It suggests that the broader implications of a debt management strategy should be carefully analyzed by debt managers and policy makers in terms of their impact on the government's balance sheet, macroeconomic developments, and the financial system.

An extensive body of literature examines how the stage of financial market development affects the structure of public debt in a country and how fiscal policy and the resulting level of debt affect macroeconomic stability. However, to the best of our knowledge, researchers have not comprehensively analyzed how debt and debt management contribute to financial stability. ${ }^{1}$ Moreover, only recently have some studies explicitly acknowledged the role of the proper management of domestic public debt in promoting macroeconomic-financial stability. Reinhart and Rogoff (2009) point out that cases of default and restructuring of domestic public debt are far more common than those of external public debt, implying that more attention should be devoted to the domestic debt episodes.

Allen and others (2002) propose a framework for exploring the debt portfolio management and macroeconomic-financial stability nexus by examining the implications of alternative combinations of cross-sectoral balance sheets within the economy. An analytical model explains a financial crisis in emerging markets as a function of the balance sheet vulnerabilities of different sectors of the economy to exogenous shocks and the way in which

\footnotetext{
${ }^{1}$ Some studies examine the contribution of the use of (public) debt as a strategic component of policy directed at increasing the level and pace of economic growth. For example, Abbas and Christensen (2007) develop a model that shows that moderate levels of debt can increase growth and higher levels can undermine it. They conclude that if domestic debt is marketable and part of it is held outside the banking system, it can contribute to economic growth.
} 
such sector-specific vulnerabilities spill over to other sectors. Rosenberg and others (2005) explore the role of (private and public sector) debt-related vulnerabilities in emerging markets' financial crises.

The lack of adequate data remains a serious constraint on this type of analysis. Jeanne and Guscina (2006) use a database on government debt covering 19 emerging market countries since 1980. They present stylized facts on debt structures and show that there are significant differences in structures across countries from different regions of the world. Using the same data set, Guscina (2008) shows that a country's debt structure often reflects its recent past macroeconomic background, which materially affects its financial stability.

Although the models developed in these papers allow for analysis in both closed- and openeconomy settings, the models have been applied primarily to open-economy settings, which allow researchers to get a better handle on the dynamics of the development of capital account crises. Clearly, however, unsustainable domestic debt levels caused by factors such as expansionary fiscal policy, under fixed-exchange rates or exchange rate bond arrangements, can also lead to currency crises, with large, discrete devaluations and substantial macroeconomic dislocation. Where ineffective capital controls are in place, financial stability can be compromised by the depletion of foreign exchange reserves (Krugman 1979). Although the story is once again one of debt levels, it highlights the constraints imposed on public debt management by macroeconomic policy and the policy regime. Public debt management represents optimization in the cost-risk space within the constraints set by macroeconomic policy; in the long run, even the best public debt managers cannot substitute for unsound policy making.

At a strategic level, debt management plays a vital role in securing the economic benefits of a sound policy framework in several ways. First, improvements in the debt structure can be an essential complement to fiscal consolidation in ensuring a robust recovery in a postcrisis environment. Second, such improvements, when implemented opportunistically (that is, during a cyclical upswing), can strengthen the effectiveness managing public debt of countercyclical macroeconomic policy going forward, at a relatively low cost. Measures include the substitution of debt denominated in domestic currency for foreign currency or foreign currency-linked debt; an extension of the maturity profile of the debt portfolio at a reasonable cost; the assignment of maturity brackets that avoid a bunching of refinancing need; and a widening of the investor base through, for example, attracting foreign investors into the domestic debt market.

The task is operationally complex and requires debt managers to make difficult trade-offs. The goal of avoiding the bunching of maturities, for example, may have to be evaluated 
against the goal of establishing an issuance volume substantial enough to ensure adequate liquidity in the security. ${ }^{2}$

A complex strategic issue for debt managers that has important implications for macroeconomic-financial stability is the decision to broaden the investor base by attracting foreign investors. Some recent studies focus on the role of foreign investors in reducing the cost of sovereign debt issuance. Peiris (2010), for example, estimates the impact of the entry of foreign investors on the volatility and level of emerging markets' government bond yields, concluding that the significant presence of foreign investors could reduce borrowing cost. It is important for governments to bear in mind the cost-risk trade-off of attracting foreign investors as a strategy for broadening the investor base.

In an ideal world, debt managers would be able to issue the low-cost paper demanded by foreign investors through a liability structure in which their exit is negatively — or weaklycorrelated with macroeconomic risk factors or exit triggers for other investors. ${ }^{3}$ If this is not possible, the low issuance cost may come at a heavy price in terms of riskiness of the debt sold to foreign investors. Although in some cases foreign lenders have contributed to the demand for longer-term instruments, in others they may prefer points on the yield curve that carry substantial refinancing risk for the sovereign; in the case of domestic debt, they may want to index the bonds to the exchange rate or the rate of inflation. Depending on the country and the point in the business cycle, this could be very risky. Carry-trade investors can be drawn in at relatively low rates conditional on maintenance of an open capital account, but resulting debt maturities are typically short and positions often rapidly unwound if macroeconomic conditions deteriorate. Thus, the volume and nature of foreign investors' presence in the domestic debt market need to be carefully assessed in raising and managing public debt.

In addition to strategic improvements through a long-term plan of action, debt managers play an important role in stabilizing markets through tactical decisions. Active liability management through tactical market intervention can serve the goal of stabilizing markets by sending an unambiguous signal regarding the debt manager's intent and ability to secure the value of its obligations to investors. Moreover, debt managers' mature perspective on the impact of alternative debt restructuring strategies on market expectations is valuable in promoting financial stability. Kumhof and Tanner (2005) observe that debt managers are more reticent than the academic literature in proposing debt default or debt restructuring, given the potential damage these events can inflict on the financial sector.

\footnotetext{
${ }^{2}$ Liquidity is often also ensured by allowing domestic debt to be used as collateral at the central bank's lending window.

${ }^{3}$ Much as in strategic asset allocation, risk hedging entails picking a portfolio across asset classes whose returns exhibit negative or weak correlation properties.
} 
The paper is organized as follows. The next section defines financial stability. The following section outlines, in general conceptual terms, the contribution of public debt and debt management to financial development and financial stability. The third section follows up with an in-depth discussion of recent country experiences that illustrate the channels through which sound debt management practices can bolster financial stability by complementing improvements to the macroeconomic policy framework. This section also outlines the relevance of these factors and channels for countries at different stages of economic and financial development. The fourth section briefly describes commonly used risk mitigation policies. The last section offers some concluding remarks.

\section{Defining FinanCial Stability}

Financial stability can be broadly considered as stability of financial markets, reflected in a low level of volatility of a number of economic and financial indicators, including prices, the money supply, credit to the private sector, the exchange rate, equity prices, bond spreads, interest rates, and cross-currency swap rates, among others. A traditional and intuitive notion of financial stability can focus on a single dimension (price) and a single characteristic (low volatility) at relevant frequencies. Some examples include the nominal exchange rate of the domestic currency, stock indexes, bond yields, oil and commodity futures, and valuation of derivatives contracts (for example, credit default swap or asset swap spreads).

Dislocations are not always accompanied, or generated, by volatility in the price domain, however. They also stem from imbalances in the quantity domain (that is, in demand and supply imbalances). A broader definition would thus encompass the magnitude and volatility of bid-ask spreads quoted by market makers and of trading volume and turnover in key markets.

Houben, Kakes, and Schinasi (2004) suggest three main roles of finance in modern economies that could help develop a broader definition of financial stability. They include the promotion of an efficient allocation of real economic resources across activities and time, the facilitation of the transformation of maturities to meet lenders' and borrowers' needs, and the appropriate pricing and management of financial risks.

Schinasi (2004) makes three observations that can be used in defining financial stability:

- $\quad$ Financial stability is a broad concept, encompassing different aspects of finance (infrastructure, institutions, and markets).

- $\quad$ Financial stability implies that resources and risks are allocated and priced efficiently and that the system of payment functions smoothly.

- $\quad$ Financial stability relates not only to the absence of financial crises but also to the inherent ability of the financial system to avoid, contain, and deal with imbalances that could pose a threat to the system or to economic processes. 
One criterion in evaluating financial stability would be whether the system allows a smooth flow of funds, so that savings can be efficiently channeled into investments. This criterion presupposes the existence of financial intermediaries that are able to efficiently manage portfolio risk. Given the centrality of government finances in most countries, it presupposes that, all other things equal, financial intermediaries are willing and able to hold government bonds that carry low default and extension risks and are liquid. Government securities are endowed with the characteristics necessary for them to constitute a benchmark relative to which the risk features of other (financial) assets in the economy can be measured. Governments, particularly debt managers, play a crucial role in securing low risk and high liquidity for sovereign bonds.

A definition that can thus be used here is "a financial system is in a range of stability whenever it is capable of facilitating (rather than impeding) the performance of an economy and of dissipating financial imbalances that arise endogenously or as a result of significant adverse and unanticipated events" (Schinasi 2004, p. 8). This definition, although flexible, may not allow for a specific quantitative measurement. The concept of financial stability needs to address possible impacts (positive and negative) of exogenous and endogenous shocks on the structure of the financial system and even to the economy in a concrete sense.

\section{Public Debt, Debt Management, and Financial Stability}

The state of government finances, financial stability, and real sector performance and prospects are codependent. This linkage becomes painfully apparent during recessions triggered by a financial crisis. It is especially apparent for banks, which typically (need to) hold an adequate quantity of government paper. They do so for several reasons: to conserve on equity capital funding cost, as the risk weight on this investment is typically nil; to meet the regulatory and internal risk limits on liquidity buffers; and to meet regulatory constraints concerning asset classes eligible for investment of regulatory capital instruments.

Reflection suggests that the linkage between government finances and financial stability is symmetric through the cycle. In an upswing, the quality of financial institutions' exposure to the government is high, as public bonds carry low default, extension, and liquidity risk. Moreover, the ease of issuance facilitates establishment of government securities as a benchmark for efficient pricing of private sector credit, often at a low spread during a boom. During a downswing, especially in the case of a recession triggered by a financial sector dislocation, maintenance of the asset quality of the government's liabilities, although far more elusive, is much more critical in containing adverse developments in the real and financial sectors.

For banks this is so because the quality of exposure to the private sector sinks rapidly, as measured in terms of either credit or liquidity risk. Government finances that are not in good order to begin with can greatly exacerbate the downturn and prolong the recovery. Recent cases of major macroeconomic-financial crises include a number of examples in which the public debt structure was in a weak starting position (for example, the debt stock was high, 
the time to maturity of a significant proportion of the outstanding volume of public sector debt was very short, or too much government debt was either floating rate or foreign currency-denominated or linked).

A weak debt structure greatly inhibits the sovereign's ability to conduct effective countercyclical macroeconomic-financial policy. Market participants typically reassess the risk of public liabilities with potentially rapid and substantial ratings downgrades, which limit borrowing capacity because of the narrowing of the investor base and the increase in issuance cost. It also exacerbates pressure on financial institutions' balance sheets, incomes, and capital reserves, particularly where marking to market of government securities in financial institutions' portfolios implies reductions in income and through an increase in the risk weight — for banks using advanced Internal Ratings Based (IRB) methodologies under Basel-II-a reduction in capital. Finally, from an investors' perspective, market pessimism can narrow the investor base for the sovereign's issues, which may translate into reduced liquidity of public debt.

The need for state-sponsored systemic bank resolution and restructuring in a recession hampers the government's ability to smoothly and credibly carry out such operations, substantially increasing the real and fiscal costs of the crisis. Rising costs, in turn, exert a negative impact on government finances, potentially generating a vicious cycle. Some of this dynamic appears to be on display in the recent crisis episodes, where the sharper real sector and labor market impact and relatively poor starting positions of the public debt portfolio in some countries fed off each other.

The debt to GDP ratio decreased in many emerging market countries over the past decade (Figure 1). The opposite pattern can be observed for most developed market economies, highlighting the increasing importance of public debt for this group of countries. ${ }^{4}$

\footnotetext{
${ }^{4}$ In addition to indicating the increased need for issuance in developed market economies following the recent global financial crisis, this pattern reflects the phenomenon of global imbalances. On the sovereign asset side, such imbalances are captured by burgeoning levels of central bank foreign exchange reserves and sovereign wealth fund asset bases in a number of emerging markets.
} 
Figure 1. Gross General Government Debt to GDP Ratio in Selected Emerging Market and Developed Market Economies, 2000 an 2009
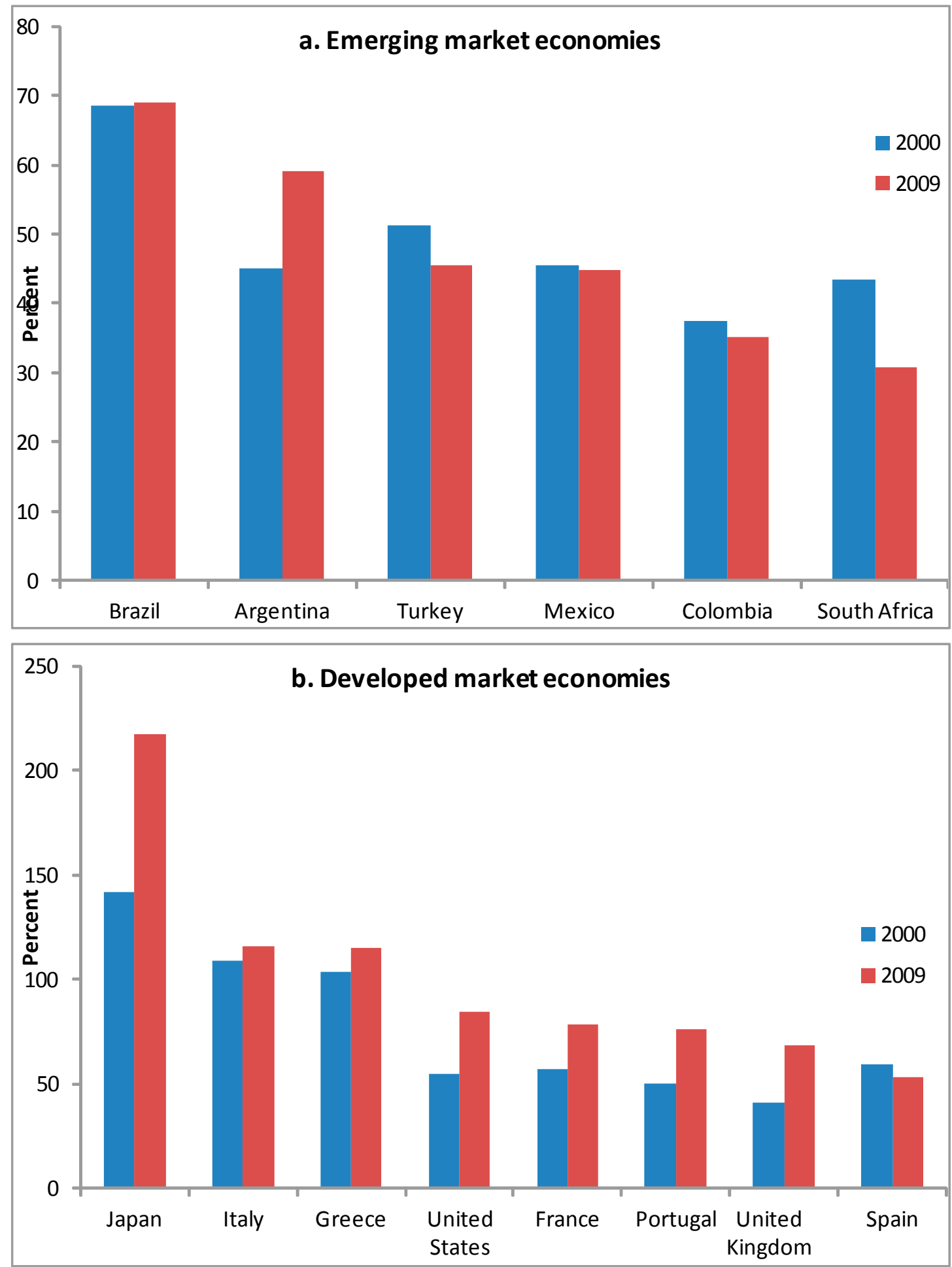

Source: IMF (2010a) 
In general, the presence of a well-functioning government debt market helps build and develop efficient financial markets. Financial market development is essential for ensuring stable economic growth. A sound financial market allows a country's savings to be channeled into investments in a more effective way. More efficient financial markets also allow for longer-term loans for individuals and companies. Such loans help boost investment in a more stable way, allowing the financial system to promote an efficient allocation of capital and transformation of maturities. Given their size and lower risk relative to other domestic issuers, public debt issues are the appropriate instrument with which to facilitate this process. The instruments should be designed to contribute to the development of deep and liquid government bond markets upon which private sector funding in the economy can be benchmarked.

Actions taken and policies implemented by debt managers can promote financial market development and financial stability. Their role has gained elevated status in the context of managing the effects of the recent crisis, during which debt levels in many countries rose significantly in a relatively short period of time. Increases in debt levels have heightened the pressure on markets to meet the higher funding needs of governments, which risks driving up yields and generating a suboptimal composition of debt structures (because, for example, of the temptation to sell a debt stock with a shorter maturity profile).

Debt management strategy is an essential complement to sound macroeconomic policies, an appropriate political environment, and the judicious choice of policy regime in achieving financial stability. It can be used at favorable points in the cycle to reduce risk at low cost. For example, fiscal consolidation in a post crisis phase is often an essential policy ingredient in ensuring a robust recovery. Its beneficial impact can be bolstered through the gradual extension of the maturity profile of public debt, changing the debt mix in favor of nominal bonds issued in domestic currency

\section{How Debt Management Affects Financial Stability: Some Recent EXPERIENCES}

This section discusses the implications of the level and composition of debt on financial stability. Analytically, financial stability can be viewed as a function of the level of the debt stock, the debt profile, the investor base, the stage of development of the capital market, and institutional factors. In what follows, we analyze the manner in which each of these factors can contribute to financial stability.

\section{A. Stock of Public Debt}

The debt stock can affect financial stability through several channels. First, as shocks to the variables that determine the value of debt instruments can influence future fiscal costs, the debt stock can affect the government's balance sheet. In this regard, debt sustainability analysis should be conducted and results closely monitored, in order to spot future solvency problems. High levels of debt should also trigger policies for mitigating possible higher 
inflation rates and, in some extreme cases, deriving restructuring schemes. In particular, if debt is too high, the sovereign's credibility becomes less ensured in the eyes of international investors, which could result in higher volatility caused by difficulties in refinancing government debt, which in turn could trigger wider financial instability.

Second, a higher stock of public debt entails a higher probability of affecting the prices of financial assets, correspondingly influencing the soundness of the financial sector balance sheet. This impact will depend not only on the amount but also on the structure of the assets held by financial institutions.

The current stock of debt is often a consequence of past monetary and fiscal policies. It is not under the control of debt managers or part of their responsibilities but rather an important input to their mandate. Debt managers must make several decisions within these constraints that can affect financial stability. In general, the higher the debt stock, the greater the impact of such decisions.

\section{B. Debt Structure and Composition}

Different sources of vulnerabilities may arise from the debt profile, depending primarily on the debt structure (the composition of debt instruments and their maturities) (Bolle, Rother, and Hakobyan 2006). Inappropriate debt structures could become channels or sources of vulnerabilities to the real economy and the financial system (Borensztein and others 2004). The debt structure should pose low risk, not only for the government but also for markets. The literature has focused on two sources of vulnerabilities, foreign currency-denominated liabilities and the short maturity of liabilities (Papaioannou 2009; for a brief overview of the literature, see Guscina 2008).

Inappropriate debt structures can lead to higher interest payments. In general, lower-cost debt structures (such as the excessive use of foreign currency-denominated debt) are subject to higher risk in the event of an unexpected shock. In the past, many emerging market countries, especially in Latin America, relied heavily on the issuance of instruments linked to the exchange rate. Mexico's case during 1994 is a good example. At the end of 1994, the Tesobonos (domestic bonds linked to the U.S. dollar) represented almost the entire stock of domestic debt, up from just 4 percent a year earlier. This increase alarmed international investors. At the end of 1994, the domestic currency was devalued. The devaluation led to a significant increase in the debt stock and consequently to significant financial instability. Not long afterward, Mexico's financial instability spread to the region. This episode is a clear example of how a poor debt structure can have adverse financial consequences (Jeanneau and Verdia 2005). After the crisis many Latin American countries improved the composition of their debt and developed their domestic debt markets, in order to become less vulnerable to debt-related shocks (Figure 2), a pattern also seen in Asia after the financial crisis that hit that region. 
Figure 2. Average Maturity of Central Government Debt

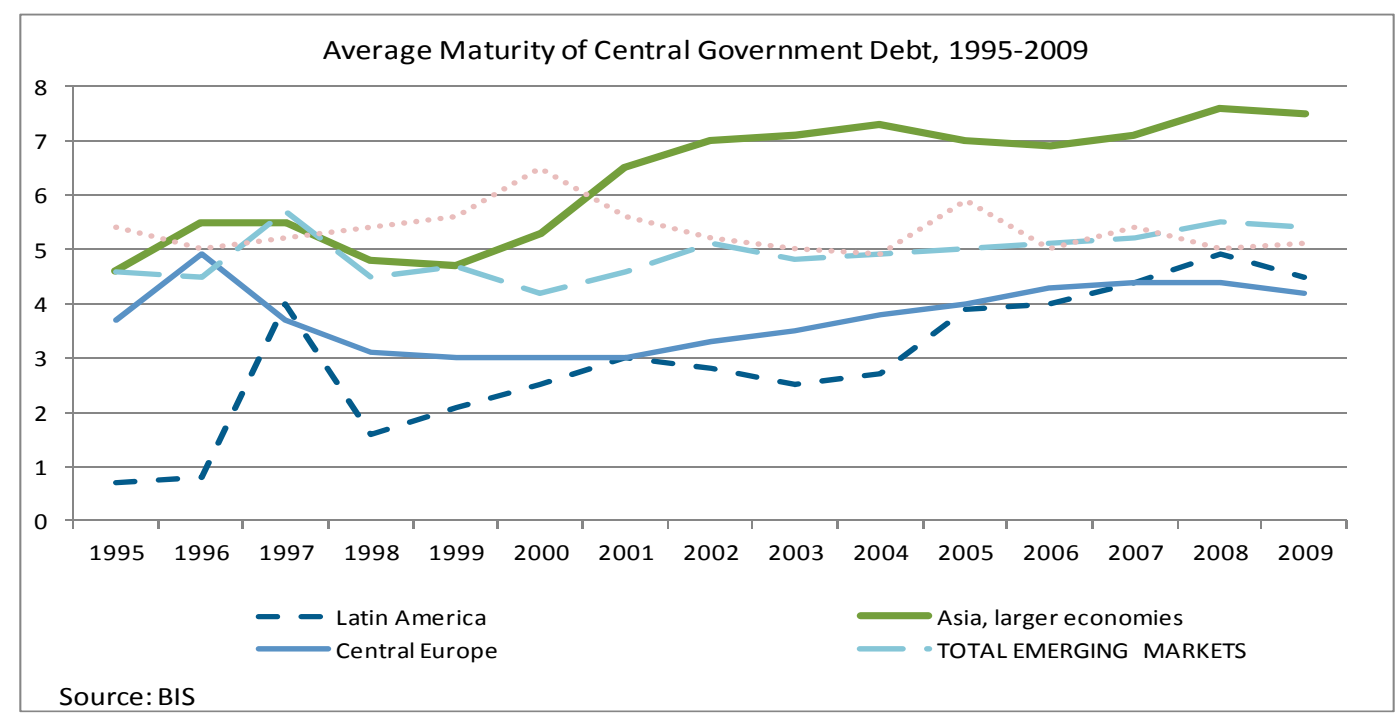

Figure 3. Domestic Debt Structure, 1995 and 2009

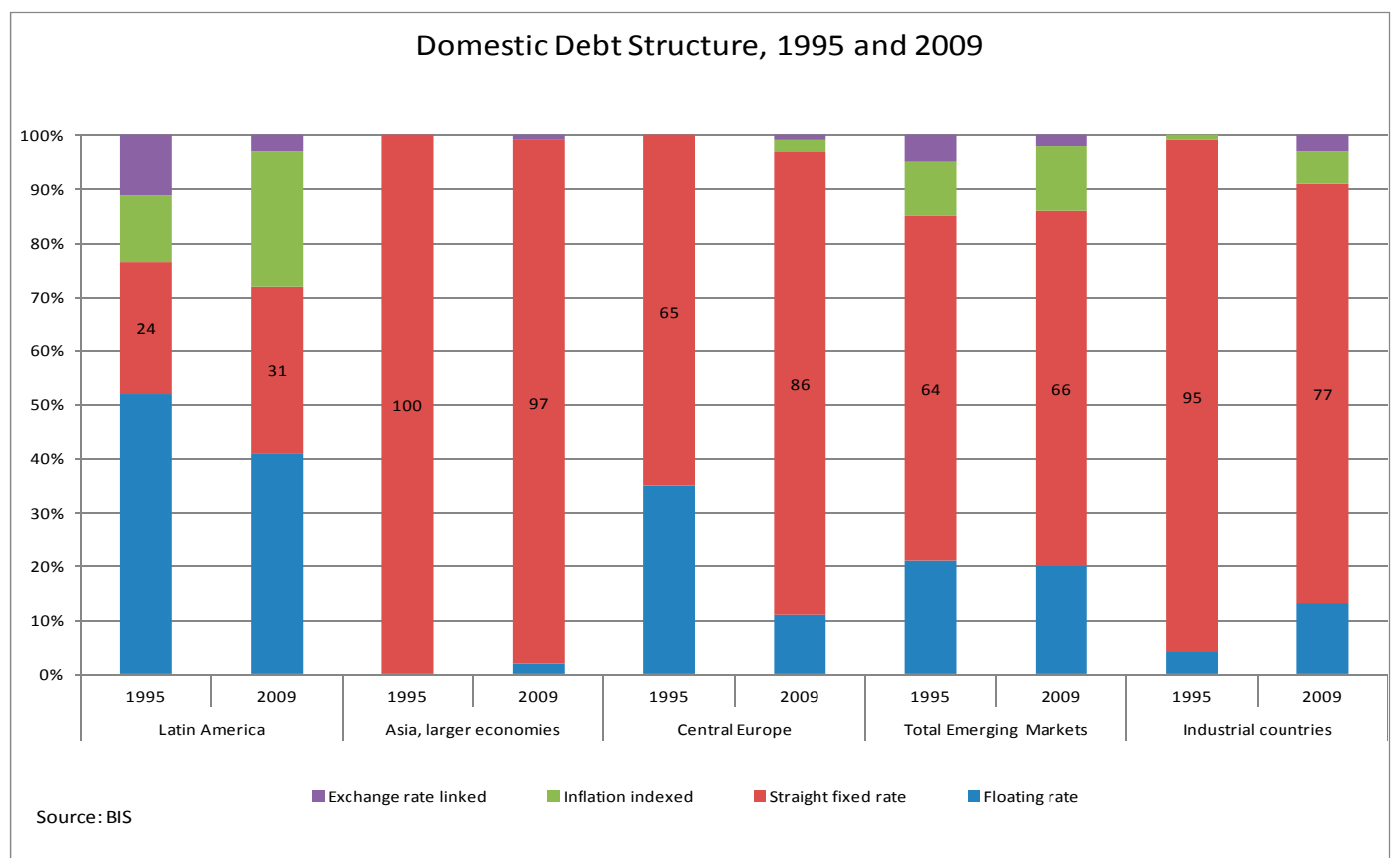

The change in the composition of domestic public debt between 1995 and 2008 clearly indicates efforts by Latin American countries to improve their debt profile (Figure 3). They did so by reducing their debt exposure through the issuance of fewer exchange-rate-linked and more inflation-linked bonds, which tend to be of longer maturity. These strategies aimed not only to reduce the foreign exchange risk but also to reduce refinancing risk.

It is possible that sound debt management choices were rendered feasible by salutary changes in macroeconomic policy regimes taken in an external environment conducive to economic recovery and growth (Figure 4). Where these policy changes were robust to domestic and 
external business cycle shocks, changes in debt structure proved to be beneficial to macroeconomic-financial stability in the longer run. In other cases, debt management efforts alone were unable to substitute for weaknesses in the policy framework to cope with cyclical shocks.

Brazil phased out exchange-rate bonds, considerably reducing exchange rate risks; for the past several years, it has tried to use floating-rate bonds and inflation-linked bonds to increase the average maturity of the debt while attempting to increase the share of fixed-rate instruments in the debt portfolio. The government also strengthened debt management capacity, through improvements in the institutional framework; establishment of regular contact with different market segments, particularly pension funds; and adoption of measures to increase liquid. Mexico underwent similar changes to improve its debt structure starting in early 2000, enhancing its resilience to crises. The measures undertaken aimed at moving toward domestic financing of fiscal deficits, lengthening the maturity structure of the public debt portfolio, and developing a liquid yield curve for domestic debt. These objectives were accompanied by a policy to increase predictability and transparency of debt issuance and to introduce a market-making scheme for government instruments.

To underscore the importance of macroeconomic stability and policy frameworks in rendering feasible sound strategic choices in debt management, we also looked at developments in Mexico starting in 1995. Mexico changed its nominal framework in response to the 1994 crisis, moving from a pegged exchange rate anchor to a floating peso with price stability anchored by an inflation-targeting arrangement. Stable exchange and inflation rates, and a high and stable domestic savings rate, were probably important ingredients in a secular lowering of nominal bond yields, which allowed for a lengthening of the maturity profile and growing issuance in domestic currency. These changes reduced refinancing risk for the government and correspondingly extension and reinvestment risk for investors.

In Turkey crisis-triggered retooling of policies on debt management enhanced resilience to financial shocks. Turkey's public balance sheet was severely weakened as a result of the banking and exchange rate crises in 2001. The bailing out of the banking sector, through the issuance of (foreign exchange-linked) government bonds led to a surge in public debt, a shortening of maturities, and greater exposure to foreign currency risks. In the aftermath of the crisis, reducing the risks from high public debt became a necessary condition for ensuring financial stability. Prudent debt management, against the backdrop of strong fiscal and growth performance, contributed to the improvement in the country's sovereign balance sheet and prospects for financial stability.

Although a virtuous combination of tight fiscal policy, falling interest rates, and strong economic growth helped reduce debt ratios, the Turkish authorities also took advantage of the favorable macroeconomic tailwind to improve the debt structure, reduce risks, and increase financial stability, including through reductions in the level and volatility of interest rates (Figure 5). For example, foreign currency-indexed domestic debt was halved between 
2002 and 2006, from 32 percent to 16 percent, significantly reducing sovereign debt exposure to exchange rate risk. The fixed rate share of domestic debt over the same period increased from 25 percent to more than 40 percent, and the share of short-term debt declined to less than 5 percent of total debt in mid-2006, down from more than 20 percent four years earlier.

In general, debt structures that rely heavily on short-term instruments are sources of vulnerability, because short average maturities entail high rollover and refinancing risk. In such cases, an increase in interest rates can have an adverse fiscal impact. Debt structures that are too short or allow for bumps in the maturity profile can potentially generate confidence crises, fueled by investors' concerns that the government will not have sufficient funds to redeem maturing bonds when they fall due. Depending on the extent of these fears, they could translate into lower demand for the country's instruments in auctions, thus triggering a self-fulfilling prophecy.

It is the debt manager's responsibility to design policies and schemes that reduce these risks. This could be done by preemptively building large cash buffers, ensuring efficient coordination with cash-management policies, and, at times, absorbing the higher cost of prefunding liability tranches maturing in the near future in order to extinguish the risk of a market call on solvency at the point of redemption. The debt structure can also impose impediments to the exercise of monetary policy. Short-term or floating-rate instruments, for instance, tend to reduce the wealth effect needed for monetary policy to be effective. If this is the case, a much stronger increase in interest rates will be needed in order to generate the same impact on the level of inflation, thus having a much higher impact on the economy.

Debt managers of countries at different levels of development (for example, Brazil, Iceland, Mexico, the United Kingdom, and the United States) are relying on the issuance of inflationlinked bonds for their funding needs. Exchange-rate bonds have proven to be riskier and sometimes deleterious to financial stability, and short-term bonds represent higher refinancing risk. Inflation-linked bonds tend to increase the average maturity of debt without increasing the exchange-rate risks faced by debt managers.

The use of this bond is also an approach to making the best use of the investor base, as some holders of debt are keen on holding this kind of instrument. However, inflation-linked bonds can increase the level of indexation in the economy, leading to higher inflation rates. Debt managers should undertake a careful assessment of such strategies, which can affect the economic performance of the country. 
Figure 4. Macroeconomic Developments in Brazil, Mexico, and Turkey, 2002-10
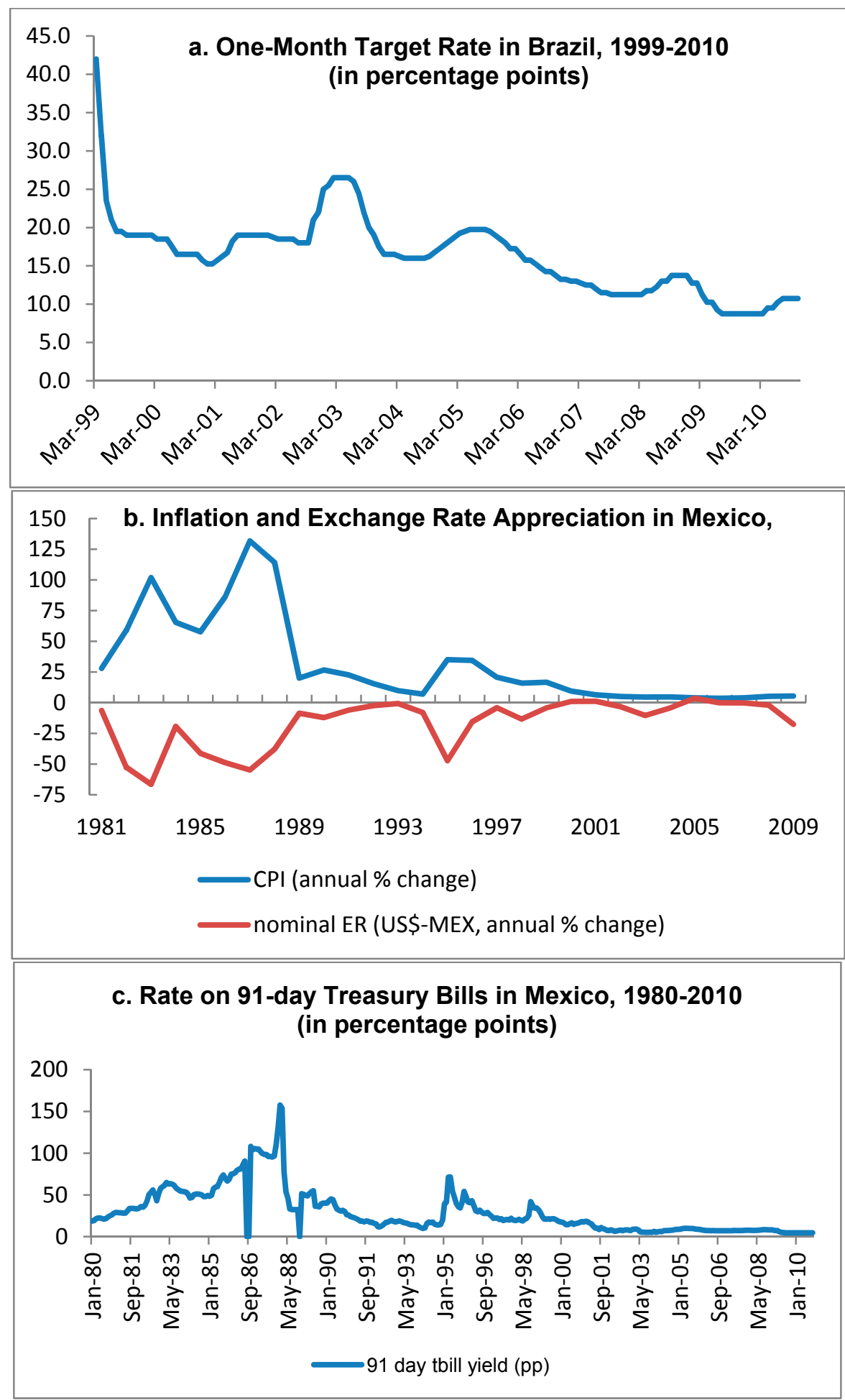

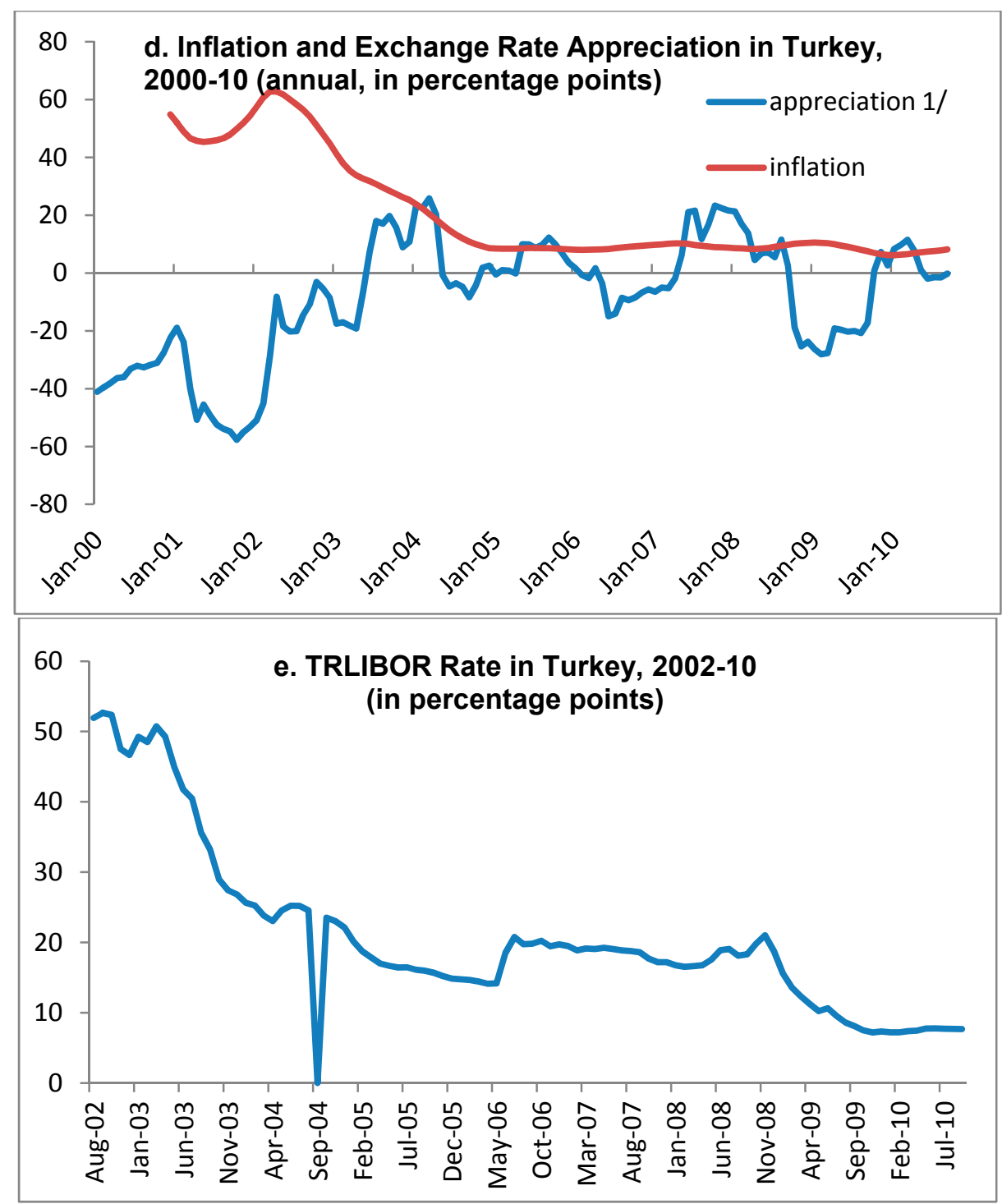

Source: Haver Analytics.

Note: SELIC is an interest rate derived by the average of one-day market rates for the Brazilian market. $\mathrm{CPL}=$ consumer price index; $\mathrm{ER}=$ exchange rate; TRLIBOR = Turkish Lira Reference Interest Rate. 
Figure 5. Composition of Public Debt in Turkey, 2002-06
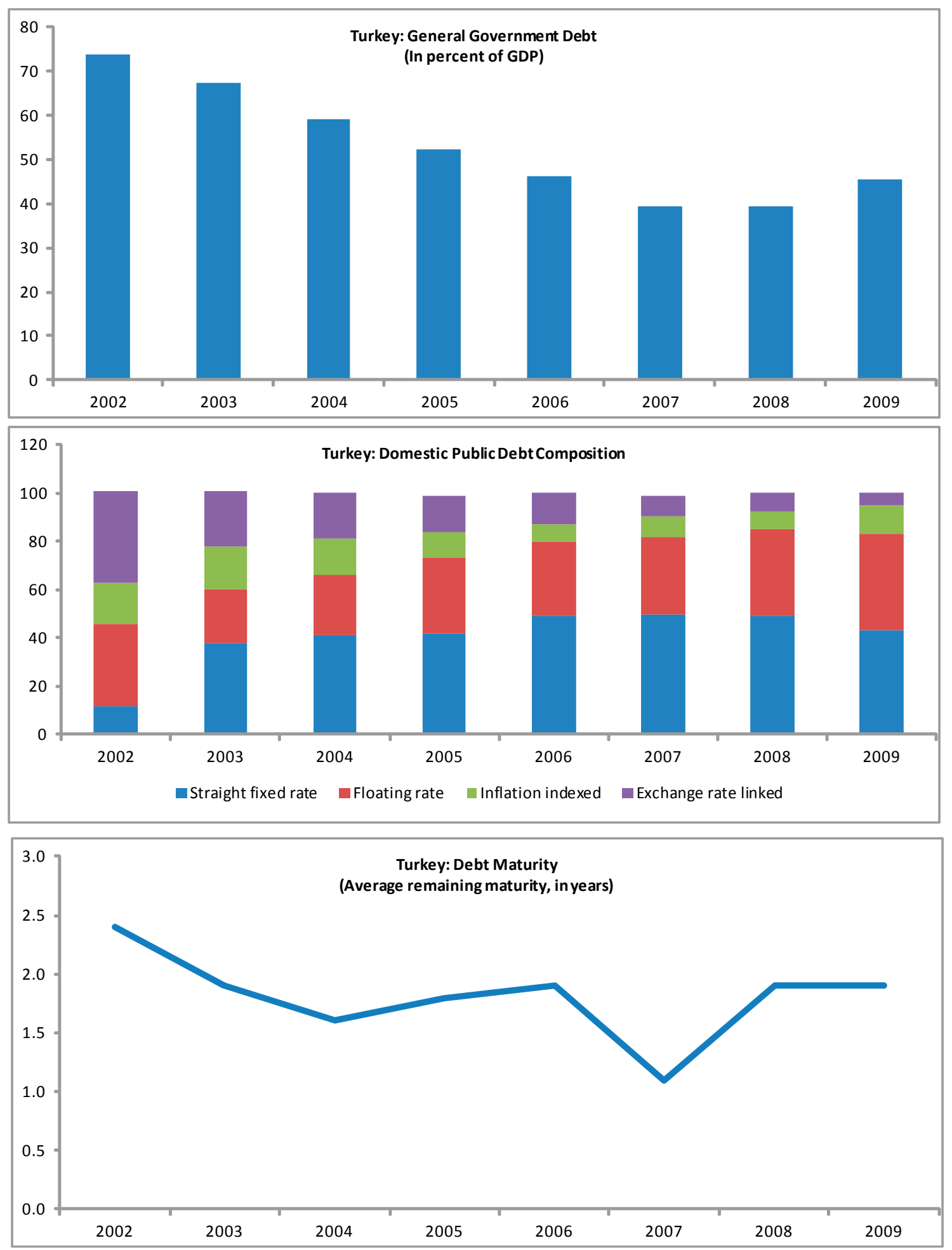

Source: IMF (2010b), and BIS. 


\section{Investor Base}

From the point of view of the debt manager, an ideal debt structure could be a fixed-rate, long-term bond portfolio. How would such a debt profile look from the investor side?

Financial institutions typically hold a significant share of public debt in most countries. ${ }^{5}$ Debt managers must recognize that their actions can have a very major impact on the balance sheets of these institutions. Moreover, given the usually high level of interdependence of financial institutions, the effects can have potential systemic implications. This impact is relevant not only when discussing possible sovereign liability management and debtrestructuring operations but also when thinking about the targeted composition of the debt.

Short-term debt involves higher refinancing risk, which could pose a higher risk to the financial stability of the country. However, longer-term debt may represent higher value at risk (VaR) for the debt holder. Fixed rate bonds pose less risk to the government but may represent a higher risk to the investor. If individual investors, in search of higher profits, increase their exposure to interest rate risk and there is a hike in interest rates, the market as a whole may suffer, because the unwinding of positions by some institutions may trigger VaR thresholds for others (for a good discussion of this topic for India, see Sy 2005). Debt managers should be aware of and try to monitor this risk.

This risk is particularly relevant for many emerging market countries, whose debt structure is still undergoing structural improvements. In these cases the pace at which the debt composition shifts toward more fixed-rate instruments and longer maturities should be carefully assessed. In Brazil debt managers regularly monitor measures such as DV0 $1^{6}$ and the VaR of the market, which provide warnings of potential distress that the market could face if interest rates rise or volatility increases. This information can be essential for assessing the implications of implementing specific strategies.

\footnotetext{
${ }^{\mathbf{5}}$ Banks demand for sovereign debt—which qualifies for a zero risk-weight under the regulatory regime they operate under - could increase under implementation of the liquidity coverage ratio (LCR) requirement proposed by the Basel Committee on Banking Supervision (BCBS) in July 2010. The LCR requires banks to maintain a stock of high-quality liquid assets sufficient to cover net cash outflows over a 30 day period under a stressed scenario. The framework differentiates between the most highly liquid assets — classified as Level 1which include zero risk weighted government securities, and other eligible liquid assets, classified as Level 2. While there is no cap to Level 1 assets that are eligible for inclusion in the LCR, the quantum of Level 2 assets is capped at 40 percent of the total admitted in the calculation of a bank's LCR. One would, therefore, anticipate an increase in the relative demand by banks for Level 1 assets in general, and sovereign debt in particular. However, since the introduction of the LCR is going to be gradually phased in through 2015 , there is no reason to anticipate discrete increases in bank demand for sovereign debt in response to liquidity rules in the near-term.

${ }^{6} \mathrm{DV} 01$ is a measure that captures the change in the value of the asset or portfolio based on a change of 1 basis point in the interest rate.
} 
In India, for example, historically low interest rates in the first half of the decade generated concerns that if and when rates rise, the position of financial institutions (heavily positioned with fixed-rate instruments) could represent problems to their balance sheets (Sy 2005). To combat this situation, during the same period, the government increased issuance of floatingrate bonds. As a result, the share of floating-rate bonds in gross market borrowing rose from 16 percent in 2003-04 to 29 percent in 2004-05.

As the investor base usually comprises banks, mutual funds, pension funds, and foreign and retail investors, debt managers must strike the right balance between meeting the specific needs of each of these groups of investors and reducing the costs to the government. Doing so entails better matching of each group of the investor base liability profile while avoiding too much market segmentation through different instruments.

Debt managers should not take the investor base for granted. Instead, they can play a preemptive role in developing the investor base further, by issuing instruments targeted at a specific group of investors and by working on increasing a specific group's participation in the debt or in particular instruments. Debt managers often issue inflation-linked bonds to satisfy demand by pension funds, for example. Brazil has traditionally attracted foreign investors for a small proportion of its domestic debt issues whose maturity structures are concentrated at the short end of the curve. A strategy was subsequently devised to issue longer-term domestic currency bonds in the international markets, create a reference point for interest rates in the domestic currency, and tap these maturities in the domestic market.

As this process moved along, it was expected that international investors would become more interested in holding domestic debt securities. Because foreign investors are usually less risk averse and tend to hold longer-term instruments, the inclusion of foreign investors in the investor base can reduce vulnerabilities associated with public debt. However, countries with a high concentration of foreign investors are more susceptible to financial crises, given that such investors are less committed to these assets.

It is therefore important to find the best balance between these factors and to come up with an appropriate share of foreign investors. If their share is too low, the country may not be taking advantage of potential benefits from a diversification in the investor base. If it is too high, the country could become vulnerable.

These examples show the sensitivity of debt management policies to financial institutions' balance sheets and financial stability. These policies call for a careful design of the instruments issued to the market; they also point to the importance of a diversified investorbase structure. Different groups of investors with different risk appetites and liability structures tend to react to new information in different ways. A diversified investor base can therefore reduce the impact of shocks. For instance, longer-term investors (such as pension funds) can reduce the impact of possible interest rate increases on the market by increasing their holdings of longer-term instruments. 
Overall, from the investors' point of view, the best instruments are those that better match their liability profile, given their return-risk characteristics. However, these instruments may not be consistent with debt managers' preferred portfolio. Striking the right balance between these conflicting objectives should be part of debt managers' discretionary decision making.

\section{Debt Capital Market Structure}

Developing a domestic debt market is an important element in the development process of a country. The functioning of the financial system depends crucially on the instruments that facilitate its operations and activities. Among the prerequisites for a well-functioning financial system are efficient liquid markets. Illiquid markets are subject to abrupt falls in asset prices, which could lead to substantial losses for financial institutions. Promoting liquidity for debt instruments should thus be an important element in the debt managers' mandate.

When implementing their strategies, debt managers should think about proper ways to facilitate bond liquidity. Doing so would not only reduce costs for the issuer, it would also enhance the efficiency of capital markets (Crocket 2008). For these reasons, it has become accepted best practice to issue benchmark securities, which are critical to creating liquid securities.

The issuance of benchmark instruments enables the establishment of an efficient "risk-free" yield curve, which can serve as a reference point for pricing other instruments issued by financial enterprises or corporations. If corporates can issue their own instruments, they rely less on direct bank intermediation, thus reducing systemic risks stemming from the financial sector. $^{7}$

Low-risk benchmark instruments can serve as efficient collateral for operations in the financial market. The existence of well-priced collaterals can reduce the transaction risk of institutions, which can use these instruments to offset credit risk. In the absence of these instruments, loans would be more expensive, issued in smaller volumes, or both. As a stakeholder in the financial system, debt management authorities should actively participate in debates on the regulatory scheme and try to affect the rules in ways that improve the effectiveness of debt management policy and ultimately strengthen financial stability.

\footnotetext{
${ }^{7}$ The extensive reliance of Asian corporates on funding to local financial institutions in the 1990s has often been cited as a major factor contributing to the Asian financial crisis of 1997-99.
} 


\section{E. Institutional Aspects}

Institutional aspects also play an important role in enhancing a country's financial stability. These aspects relate to coordination schemes with other policies, the legal framework, and communications with relevant stakeholders.

Proper coordination between debt management and monetary policy tends to result in better signaling of government intentions and increase transparency. Because monetary and debt management policies coexist in the same market, it is crucial to ensure good coordination mechanisms. In many countries lack of proper coordination has resulted in competing auctions and market confusion regarding the true signals of monetary policy. Similarly, poor coordination with cash management can increase refinancing risks, if the availability of funds at short notice is at risk.

Another important aspect that should not be neglected is the structure of the legal framework for debt management. An inadequate legal framework can lead to debt management structures that are too rigid (for example, structures that do not allow debt managers to buy or sell instruments at a price different from par or set budget limitations on specific types of instruments).

Communications with market participants need to strike the proper balance between transparency and flexibility. Striking such a balance can decrease costs over the medium term and minimize volatility in the market, if communications avoid sending mixed signals to the market. Debt strategies that are not properly communicated are not transparent, or present abrupt changes in direction can result in constant shifts in the investor's portfolio. Under such conditions, investors cannot hold positions based on a medium-term view; instead, they have to keep changing instruments based on rumors and perceptions, which increases their risk and the costs to the government. Cross-country experience shows that predictable and transparent debt management strategies tend to result in lower costs and less volatile markets.

Qualified staff is also important. Lack of expertise may lead a country to fail to understand all of the links to financial stability, potentially incurring higher risks.

\section{Relevance of DebT Management for VARious Groups of Countries}

In many developing economies, where debt capital markets are not yet fully structured, there may not be scope for issuing government bonds. In these cases debt is made up mainly of loans and nontraded securities, held largely by banks or suppliers. Often there is no secondary market in which securities are traded. Where a yield curve is defined, it could serve as a reference for pricing other financial assets in the economy. In the absence of traded bonds, central banks cannot rely on nontraded instruments for monetary policy operations. They must adopt more direct mechanisms. Therefore, the absence of traded debt instruments may lead to suboptimal monetary policy. 
The existence of relatively developed debt markets could inhibit monetary financing of the deficit, which can itself be a source of vulnerability. Countries with less developed debt markets tend to face weaknesses related to the monetary link between debt management and financial stability. Therefore, developing the local debt market is a basic step that countries should take to achieve financial stability. The development of local markets is a necessary but not sufficient condition for financial stability, as evidenced in recent episodes in developed market economies. ${ }^{8}$

For many emerging market countries, all the channels mentioned above are broadly relevant. Their debt structures have not yet reached a steadystate level, implying fiscal risks, suboptimal monetary policies, or both. Moreover, the investor base is not sufficiently diversified, making volatility in bond prices higher than would otherwise be the case.

Developed markets usually do not encounter the problems mentioned above, and debt management does not face the same constraints as in less mature markets. However, debt and debt management have become more relevant for this group of countries. The sharp increase in the stock of sovereign debt in many mature economies since 2008 has made it a particularly pressing issue. Many of the points raised above will have to be addressed.

In some developed countries with high levels of government debt, the investor base could be a source of vulnerability. In these cases a fall in bond prices coupled with an unwillingness of counterparties to buy these bonds can lead to liquidity or even solvency problems. In an environment of increased stock of debt and reduced appetite for government securities, another potential problem is the increase in refinancing risk (caused by the rise in solvency/liquidity risks), which can raise funding cost significantly. The framework presented above can be useful for these countries in assessing the level of debt, its composition, the structure of the investor base, and relevant institutional aspects.

\section{Risk Mitigation Policies}

When debt markets become unstable and financial stability is endangered by their behavior, debt managers can play an important role in smoothing market distortions. During the recent global financial crisis, for example, debt managers in developed markets made dealership rules more flexible in an effort to relieve the pressure on banks' balance sheets. In many emerging market countries, governments have intervened in the bond market through different auction mechanisms to stabilize bond prices.

In Brazil, for example, during a period of turbulence in 2008 , foreign investors sold off bonds in the domestic market. This action triggered sales orders by other investors, leading to a sharp increase in yields (Figure 6). Debt managers intervened by conducting simultaneous

\footnotetext{
${ }^{8}$ In general, there is no simple causality between the stage of financial market development and financial stability.
} 
buy and sell auctions, which were successful in stabilizing yields immediately. Investors' perception that debt managers would not allow a sharp depreciation of its liabilities played an important role in stabilizing the bond market and preventing external turbulence to spread and undermine domestic financial stability.

Kumhof and Tanner (2005) note that debt managers are more careful in dealing with debt defaults or debt devaluations than the academic literature indicates, because they consider the impact of their decisions on financial system stability. Debt management remains extremely relevant when a debt restructuring or debt default is considered. In cases where the government will need funding to go forward, the outcome of such a deal is crucial: badly conducted debt management could impair the government's ability to keep raising money efficiently in the markets. In cases of debt restructuring, it is imperative for debt managers to provide assessments on a broad range of topics, such as instruments to be issued and exchanged, haircut levels, and timing of operations.

In Uruguay the broadly voluntary nature of the 2003 debt restructuring succeeded in affecting investors only mildly. As a result, the restructuring did not significantly damage Uruguay's ability to raise funds in the market. Indeed, the government was able to access international markets for new funding in October 2003, only five months after the restructuring was completed. Debt management helped ensure that the process of restoring financial stability was smooth.

The experience with Jamaica's debt restructuring was similar. In the recent past, Jamaica faced severe debt sustainability problems, and many investors considered default imminent. Default would have triggered significant losses to the financial system, which was dominated by securities dealers heavily exposed to domestic debt. The authorities therefore opted for a solution that would not only reduce fiscal costs without putting too much pressure on financial institutions but would also ensure market accessibility. ${ }^{9}$

Houben, Kakes, and Schinasi (2004) suggest some tools to address financial stability for each of the following three phases: prevention (implementing existing policies to safeguard financial stability), remedial action (implementing preemptive measures to reduce emerging risks to financial stability), and resolution (reactive policy interventions aimed at restoring financial stability). Debt management has a role to play at each stage (Table 1).

\footnotetext{
${ }^{9}$ The government used the call option feature of the old bonds to induce investors to exchange those higher coupon-bearing instruments for new bonds with lower coupons.
} 
Figure 6. Buy and Sell Auctions in Brazil, 2006 and 2008

Buy and Sell Auctions in Brazil, 2006 and 2008

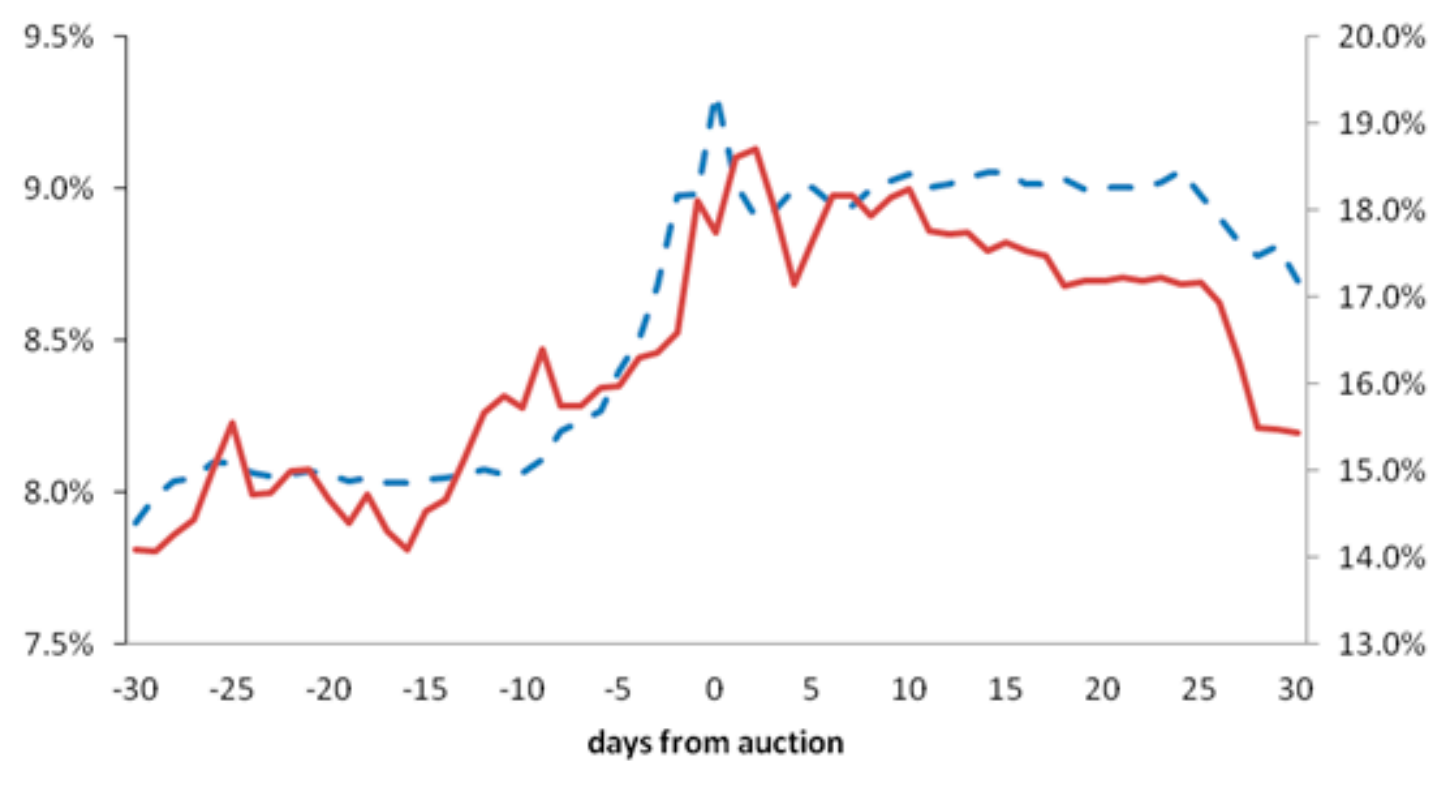

- - May/06 (NTN-B 2045)- left axis October/2008 (NTN-F 2017)- right axis

Source: Brazilian National Treasury; Andima

Table 1. Debt Management Channels to Financial Stability

\begin{tabular}{|c|c|c|}
\hline Channels & Preemptive Policy & Risk Mitigation Policy \\
\hline Stock of Debt & Issue low cost, low risk instruments & Debt buy backs, debt exchanges \\
\hline Profile of Debt & Issue low cost, low risk instruments & Exchange auctions, derivatives \\
\hline Investor Base & $\begin{array}{l}\text { Diversify investor base; monitor investor- } \\
\text { base risk indicators and adapt appropriate } \\
\text { strategy }\end{array}$ & $\begin{array}{l}\text { Debt by backs, exchange } \\
\text { auctions, Investors relations } \\
\text { program }\end{array}$ \\
\hline Debt Market Structure & $\begin{array}{l}\text { Issue benchmark securities; establish } \\
\text { appropriate primary dealers and market- } \\
\text { makers structure; coordinate with } \\
\text { regulatory bodies; put in place appropriate } \\
\text { legal framework; draft debt market } \\
\text { development strategy }\end{array}$ & $\begin{array}{l}\text { Changes in legal framework and } \\
\text { debt strategy }\end{array}$ \\
\hline Institutional Aspects & $\begin{array}{l}\text { Coordinate with monetary policy and } \\
\text { cash-management policy; maintain good } \\
\text { communications channels; adopt a well- } \\
\text { thought-out program, taking into account } \\
\text { international practices and domestic } \\
\text { idiosyncrasies and constraints }\end{array}$ & $\begin{array}{l}\text { Changes in legal framework and } \\
\text { debt strategy }\end{array}$ \\
\hline
\end{tabular}

Source: Authors. 


\section{CONCLUding ReMARKS}

Inappropriate debt structures and poor debt management can greatly inhibit a sovereign's ability to ensure financial stability by affecting investors' country risk perception and exacerbating pressures, initially on financial institutions' balance sheets, incomes, and capital reserves and ultimately on sovereign balance sheet, thereby raising sovereign risks. The interlinkages between financial stability and sovereign risk can operate through a feedback loop: poor debt management can worsen financial stability which in turn can amplify sovereign risk and heightened sovereign risk can further reduces government's ability in supporting financial stability. Some of these effects appear evident in the recent crisis episodes, during which relatively poor public debt portfolio initial positions in some countries adversely affected both economic performance and financial stability.

Sound debt management strategies can be instrumental in ensuring financial stability, by creating a liability structure for public debt that sustains low levels of refinancing risk for the sovereign throughout the business cycle and by securing the sovereign's ability to issue the necessary volume of debt at a reasonable cost in a downswing. Debt managers have a broad range of responsibilities, including formulating and implementing the strategy; determining the instruments that will be offered to the market and their timing; and handling institutional matters and interaction with investors, taking into account investors' risk constraints and appetites at every point in time, all of which affect financial stability.

In addition, an often overlooked contribution of a sound debt management strategy is the efficacy of tactical liability management operations, in which debt managers credibly intervene in domestic debt markets in emergency situations and quickly rebuild investor confidence. The low level of market development in most developing countries, the still vulnerable structures of debt in many emerging markets, and the rise in debt levels in a number of developed economies make sound sovereign debt management even more challenging for global financial stability in the future, particularly given the higher global funding pressures. Understanding the risks and the channels of their transmission to financial stability is an essential element of formulating appropriate policies for strengthening domestic and international financial stability. 


\section{References}

Abbas, S. M. Ali, and Jacob E. Christensen, 2007, "The Role of Domestic Debt Markets in Economic Growth: An Empirical Investigation for Low-Income Countries and Emerging Markets,” IMF Working Paper No. 07/127 (Washington: International Monetary Fund).

Allen, Mark, Christoph Rosenberg, Christian Keller, Brad Setser, and Nouriel Roubini, 2002, "A Balance Sheet Approach to Financial Crisis," IMF Working Paper No. 02/210 (Washington: International Monetary Fund).

Andina, 2010, Database. Available via the Internet: $\underline{h t t p: / / w w w . a n d i m a . c o m . b r . ~}$

Bank for International Settlements, 2007, "Financial Stability and Local Currency Bond Markets," CGFS Paper 28 and updates, Committee on the Global Financial System (Switzerland: Basel).

Bolle, Monica, Bjorn Rother, and Ivetta Hakobyan, 2006, "The Level and Composition of Public Sector Debt in Emerging Market Crises,” IMF Working Paper No. 06/186 (Washington: International Monetary Fund).

Borensztein, Eduardo, Marcos Chamon, Olivier Jeanne, Paolo Mauro, and Jeromin Zettelmeyer, 2004, Sovereign Debt Structure for Crisis Prevention," IMF Occasional Paper 237 (Washington: International Monetary Fund).

Brazilian National Treasury, 2010, Debt Management Office, Secondary Market Data, Brazilia.

Crocket, Andrew, 2008, "Market Liquidity and Financial Stability," Financial Stability Review, Special Issue on Liquidity 11 (Paris: Banque de France, February).

Guscina, Anastasia, 2008, "Impact of Macroeconomic, Political, and Institutional Factors on the Structure of Government Debt in Emerging Market Countries," IMF Working Paper No. 08/205 (Washington: International Monetary Fund).

Haver Analytics, 2010, Database. Available via the Internet: http://www.haver.com.

Houben, Aerdt, Jan Kakes, and Garry Schinasi, 2004, "Toward a Framework for Safeguarding Financial Stability,” IMF Working Paper No. 04/101 (Washington: International Monetary Fund).

International Monetary Fund, 2010a, Historical Public Debt Database. Available via the

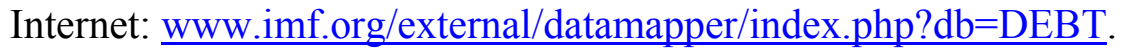

, 2010b, World Economic Outlook Database. Available via the Internet: http://www.imf.org/external/pubs/ft/WEO/2010/01/weodata/index.aspx. 
Jeanne, Olivier, and Anastasia Guscina, 2006, “Government Debt in Emerging Market Countries: A New Data Set,” IMF Working Paper No. 06/98 (Washington: International Monetary Fund).

Jeanneau, S., and C. P. Verdia, 2005, "Reducing Financial Vulnerability: The Development of the Domestic Government Bond Market in Mexico," BIS Quarterly Review (December), pp. 95-107.

Keller, Christian, Peter Kunzel, and Marcos Souto, 2007, "Measuring Sovereign Risk in Turkey: An Application of the Contingent Claims," IMF Working Paper No. 07/23 (Washington: International Monetary Fund).

Krugman, P., 1979, “A Model of Balance of Payments Crisis," Journal of Money, Credit, and Banking, Vol. 11, pp. 311-25.

Kumhof, Michael, and Evan Tanner, 2005, "Government Debt: A Key Role in Financial Intermediation,” IMF Working Paper No. 05/57 (Washington: International Monetary Fund).

Papaioannou, Michael, 2009, "Exchange Rate Risk Measurement and Management: Issues and Approaches for Public Debt Managers," South-Eastern Europe Journal of Economics, Vol. 7, No. 1, pp. 7-34.

Peiris, Shanaka Jayanath, 2010, "Foreign Participation in Emerging Markets' Local Currency Bond Markets," IMF Working Paper No. 10/88 (Washington: International Monetary Fund).

Reinhart, Carmen, and Kenneth Rogoff, 2009, "This Time Is Different: Eight Centuries of Financial Folly" (Princeton, New Jersey: Princeton University Press).

Rosenberg, Christoph, Ioannis Halikias, Brett House, Christian Keller, Jens Nystedt, Alexander Pitt, and Brad Setser, 2005, "Debt-Related Vulnerabilities and Financial Crises: An Application of the Balance Sheet Approach to Emerging Market Countries," Occasional Paper 240 (Washington: International Monetary Fund).

Schinasi, Garry J., 2004, “Defining Financial Stability,” IMF Working Paper No. 04/187 (Washington: International Monetary Fund).

Sy, Amadou, 2005, "Managing the Interest Rate Risk of Indian Banks' Government Securities Holdings," IMF Working Paper No. 05/78 (Washington: International Monetary Fund). 